Iberian Journal of the History of Economic Thought

ISSN-e: 2386-5768

http://dx.doi.org/10.5209/ijhe.64673

\title{
The place of The General Theory in the economics canon
}

Constantinos Repapis ${ }^{1}$

Recibido: 14/06/2019 / Aceptado: 12/03/2020

\begin{abstract}
This paper presents in non-technical language an interpretation of the argument of The General Theory, which is the importance of effective demand and its relation to human agency. It argues that The General Theory is not only a treatise on economic theory, but also, and more importantly, a treatise on methodology, i.e. how economists should reason when dealing with the complexity of the real world. Implicit in this analysis is a distinct position on the remit of the economist and the nature of economic advice and policy. This interpretation suggests that this understanding forms a new paradigm of thinking about the economy at large, centred around the concept of uncertainty. This insight developed into a new analytical tradition in economics, the Post-Keynesian School of economic thought that sees uncertainty and effective demand as the key analytical long-term concepts for understanding how the economy evolves through time.
\end{abstract}

Keywords: J.M. Keynes; Post Keynesian Analysis; Uncertainty; The General Theory

JEL codes: B20, B31, B41

\section{[es] El papel de la Teoría General en el canon de economía}

Resumen. Este artículo presenta en un lenguaje no técnico una interpretación del argumento de The General Theory, que es el de la importancia de la demanda efectiva y su relación con la agencia humana. Abunda en la idea de que The General Theory no es solo un tratado sobre teoría económica, sino también, y lo que es más importante, un tratado sobre metodología, es decir, sobre cómo los economistas deben razonar cuando tratas la complejidad del mundo real. En este análisis hay implícita una posición sobre las competencias de un economista y la naturaleza de la política y asesoramiento económicos. Esta interpretación sugiere que ello forma parte de un nuevo paradigma de pensamiento económico, centrado en el concepto de incertidumbre. Esta se convirtió en una nueva tradición analítica en economía, la Escuela de pensamiento económico poskeynesiano que considera la incertidumbre y la demanda efectiva como los conceptos analíticos clave a largo plazo para comprender cómo evoluciona la economía en el tiempo.

Palabras clave: J.M. Keynes; Análisis postkeynesiano; Incertidumbre; Teoría General

Códigos JEL: B20, B31, B41

Sumario: 1. The General Theory as an alternative approach to an understanding of the economy. 2. Production and effective demand. 3. Human agency, uncertainty and unemployment. 4. The general theory's view on material civilization. 5. The General Theory and the Post-Keynesians. References.

Cómo citar: Repapis, C. (2020): "The place of The General Theory in the economics canon” en Iberian Journal of the History of Economic Thought 7(1), 79-92.

\section{The General Theory as an alternative approach to an understanding of the economy ${ }^{2}$}

Interpretations of The General Theory abound, but they usually use technical language or specific models to make their point and, very rarely discuss in some depth what is the unifying vision of the General Theory that makes it distinct to the classical and neoclassical perspectives of the economy. At the same time simple accounts produced for leisurely reading rarely reveal the complexity of the text that makes The General Theory defy any simple interpretation. ${ }^{3}$

\footnotetext{
Institute of Management Studies, Goldsmiths, University of London. c.repapis@gold.ac.uk

In this paper I use the term "approach" as it is utilised by Harcourt (1987A) who notes that "post-Keynesian economics is a portmanteau term which is used to contain the work of a heterogeneous group of economists who nevertheless are united not only by their dislike of mainstream neoclassical theory and the IS/LM general equilibrium versions of 'Keynesian' theory but also by their attempts to provide coherent alternative approaches to economic analysis.... We say 'approaches' because several strands can be identified". (Harcourt, 1987A, p 924) This paper follows a specific interpretative line within the diverse school of Post-Keynesian economics, and the theorists that relate with this approach are discussed in section 5 of the paper.

3 There is a large literature of readings popularising Keynes, his life and his message for the non-specialist reader (recent contributions include - not a complete list-Cord, 2007; Davidson, 2007; Sheehan, 2009; Clarke, 2009; Skidelsky, 2010; Hayes 2019, and for a variety of introductory readings on the diverse Keynesian traditions see Repapis, 2014). What is attempted here is to add to this literature by making clearer first the overall structure of a specific interpretative tradition of The General Theory and then in explaining the central insight of uncertainty in ways that are different to most of these popularisations. The suggestion, however, is not to argue for only this perspective at the exclusion of all others, as indeed, the paper argues in favour of a plurality of approaches of both seeing the economy and in interpreting Keynes' General Theory.
} 
Therefore, this paper intends to present an account of the central unifying theme of The General Theory in a non-technical way and introduce key differences to classical and neoclassical economics. At the same time it can act as a key to re-reading The General Theory and reasoning from it anew. This reading follows a specific interpretative approach of what is the main message of the book, and this is discussed in the concluding section.

A good starting point may be to use Lionel Robbins's definition of economics, which is that economics is "the science which studies human behaviour as a relationship between ends and scarce means which have alternative uses" (Robbins, [1932] 1935, 16). ${ }^{4}$ The focus of this definition is the idea that modern society is defined predominantly by people who have enough freedom to make meaningful consumption and other important life choices. From this starting point, economics develops a technical tool-box that analyses these choices, and therefore the way individuals interact in a variety of institutional environments. This approach is generally termed neoclassical, as it emanates from the writings of Stanley Jevons, Vilfredo Pareto, Carl Menger, Alfred Marshall and Léon Walras, who are the theorists that systematized this individual-based conception of economics, and brought it to be the foundation through which to analyse the modern economy. It may be useful to call this type of economics neoclassical or the 'economics of scarcity', for want of a better shorthand.

There is an older tradition ${ }^{5}$ that goes back to classical political economy, and particularly the work of David Ricardo, that focuses on the substantial productive capacity of the modern capitalist economy. David Ricardo in The Principles of Political Economy and Taxation (1817) created a system that analysed the economy with logical consistency but at a high level of abstraction. He was quick to observe, that although some rare items - like old paintings or fine wines - have their value and price determined by their scarcity, they are not what really forms the main everyday part of market transactions. Thus, he considered these goods not the norm in an industrialised society. Instead, what really determines value for most things, and therefore is the ultimate determinant of price in an industrialised economy, is the cost of production of goods. ${ }^{6}$ From this insight, Ricardo proceeds by arguing that society is made of different classes, and that "the produce of the earth -all that is derived from its surface by the united application of labour, machinery, and capital- is divided among three classes of the community, namely, the proprietor of the land, the owner of the stock or capital necessary for its cultivation, and the labourers by whose industry it is cultivated" (Ricardo, [1817] 1911, 1). Therefore, "to determine the laws which regulate this distribution is the principal problem in Political Economy" (Ricardo, [1817] 1911, 1). It may be useful to call this type of economics, classical, or the "economics of production and distribution", for want of a better shorthand.?

How does all this help us understand The General Theory? I will start with the following digression: Keynes in 1940 wrote a pamphlet titled How to Pay for the War and sent it to an intellectual friend of Lionel Robbins, F.A. Hayek, who in his reply letter, noted the following: "It is reassuring to know that we agree so completely on the economics of scarcity, even if we differ on when it applies" (quoted in Skidelsky, 2006, 83). Keynes, according to Hayek's comment, was not against the whole framework of neoclassical economics and its ethical, technical and analytic arguments but, more substantially, saw the limitations of this approach as a general system of analysis. Thus, the book is called The General Theory, exactly because he was building a framework that intended to envelop this economics as a special case. In The General Theory itself, in chapter three where Keynes introduces the principle of effective demand, he writes that in his new scheme "we shall find that the theory of prices falls into its proper place as a matter which is subsidiary to our general theory" (Keynes, 1936, 31-32).

It is reasonable to assume that the above quote relates to prices as determined by market valuations, and therefore the analytical devices of "the economics of scarcity". However Keynes in The General Theory uses broadly, and at times provocatively, the term Classical economics to refer to all economics before him, brushing aside the differences in the two traditions that were discussed briefly above. So to which tradition is he referring to in the above passage, the classical or the neoclassical one?

On December 31, 1933, the New York Times published an open letter by Keynes to the new president of the US. F.D. Roosevelt. Therein he writes:

You are engaged on a double task, recovery and reform; recovery from the slump and the passage of those business and social reforms which are long overdue. For the first, speed and quick results are essential. The second maybe urgent too; but haste will be injurious and wisdom of long-range purpose is more necessary than immediate achievement. It will be through raising high the prestige of your Administration by success

\footnotetext{
The definition that ties economics with choice under scarcity is now commonplace in most economics' textbooks.

And there are other perspectives and types of analysis in economics that this paper will not go into, as they are not pertinent to this story.

How exactly this cost can be defined is a complex question that, to some degree, still has not received a satisfactory answer- even to those that follow this school.

Another way to distinguish the two traditions is to call one a (classical) surplus theory, as it focuses on the surplus created over what is needed for the reproduction of existing production potential, and the other (marginalist) scarcity theory. This is the terminology used in (Martins, 2014) which has a good introduction to the two approaches (see pages 3-34). I refrain from using this terminology here to avoid confusion, as surplus is discussed extensively in Section 4.
} 
in short-range recovery, that you will have the driving force to accomplish long-range reform.

On the other hand, even wise and necessary reform may, in some respects, impede and complicate recovery. For it will upset the confidence of the business world and weaken their existing motives to action, before you have had time to put other motives in their place. (Keynes, 1933 [1982], 290-1)

This passage sets out exactly how Keynes thought about things. This is that long-term considerations of production and distribution come after remedial measures for recovery have been made in an economy suffering from unemployment and general economic depression. In short, Keynes' economics can be seen as a generalisation of the classical system, in the following way: If the pre-condition of full employment is observed, something that cannot be assumed to be automatically observed in a modern economy, then questions on the distribution of the product of society can be discussed, and policies that deal with altering what different parts of society receive put on the table in this new environment. However, if Keynes is generalising the classical model, what of neoclassical analysis? What is its space and domain? Does his system add to and extend the classical or the neoclassical point of view? Opinion on this is divided, and this gives rise to different interpretative traditions on Keynes' General Theory. In this paper, I follow a particular strand of Post-Keynesian analysis to argue that there is method in his madness, and that he is doing something quite different to simply extending either approach.

This paper argues for an interpretation that sees The General Theory, and Keynes' mature thoughts on economics, as distinct to both perspectives and forming its own approach - even if it borrows strongly from both. It is distinct because it is a system of analysis complete in itself that cannot be either reduced to or seen as a straight forward extension of the analytical framework and general vision of society of the neoclassical or the classical system. This view can be termed "the economics of fundamental uncertainty", or "the economics of effective demand", which I am going to use as part of the same family of definitions.

The paper is structured as follows. Section 2 presents production and effective demand as it relates to short period analysis, and its links with classical economics, which is one of the most well-known aspects of Keynesian theory. Section 3 adds to the above analysis the role of human agency and how this relates to the core concept of uncertainty. I argue that given the nature of the individual and the problem of market valuation of goods, the market of labour becomes a core mechanism in how the individual sees society and their place in it. Section 4 links the above discussion with the General Theory's overall vision of how material civilization is created and sustained, and the role that economists are expected to play. Section 5 offers some concluding thoughts and con- nects this interpretation of the General Theory with the work of key Post-Keynesian writers.

\section{Production and effective demand}

Keynes starts his analysis of the postulates of classical economics, (chapter 2) with the following lines:

Most treatises on the theory of value and production are primarily concerned with the distribution of a given volume of employed resources between different uses and with the conditions which, assuming the employment of this quantity of resources, determine their relative rewards and the relative values of the products (Keynes, 1936, 4).

He adds in a footnote that "this is the Ricardian tradition. For Ricardo expressly repudiated any interest in the amount of the national dividend, as distinct from its distribution" (stress in the original, Keynes, 1936, 4: footnote 1).

The interest in the amount of production the economic system can produce, but may not be actually producing, is central to The General Theory. It is central because it can give us a number of useful ways to see the economy and its processes at any particular point in time. This comes in full force in book III where Keynes develops one of the central tools of this new economics, the multiplier. In chapters 8 and 9 he discusses the objective and subjective factors that form the short-period conditions of the aggregate consumption function and the marginal propensity to consume. The argument, although presented in a simple way, is quite complex. For the subjective factors - the motives that guide consumption for the individual- he claims that while these vary widely between societies, for each given society at every given time, "the distribution of wealth is determined by the more or less permanent social structure of the community" (Keynes, 1936, 110). He adds that this factor can be taken as given in the short run. Thus, people consume as their habits, social position, etc. dictate and these things are predictable enough in the short run to be taken, on average, as objective facts. This makes him conclude that what partly determines consumption in the short run is the available disposable income that the members of the community have, and therefore factors that have to do with production. And he proceeds with this thought to its natural conclusion: "given the general economic situation, the expenditure on consumption in terms of the wage unit depend in the main, on the volume of output and employment" (Keynes, 1936, 96). This leads him to chapter 10 , to the full development of the concept of the multiplier, which is a relationship between aggregate employment, income and the rate of investment. Through this we have a simple heuristic which tells us how increasing, for example, government expenditure, will impact on employment and output in the short run. 
This may sound fairly obvious. However, the deeper ramifications of this analysis are both radical and controversial. First, it assumes that there is a determinate relationship between changes in aggregate income, investment and total employment which can be discovered -through empirical testing and good judgment on the part of the economist- and then leaned on to precipitate changes in the volume of employment and income. The larger argument is that the economist can identify what the market cannot - the opportunities to increase employment and output without, as such, leading to a radically new distribution of income in society at large, but only in aggregate scaling up total income by giving wages to currently unemployed workers. This starts a virtuous process through which labourers have an income, can consume and survive, entrepreneurs have someone to sell goods to and have a reason to increase production and further invest as their spirits improve due to the increased demand.

All this can continue until we reach the point of effective demand. ${ }^{8}$ This means that we can see demand in this economy in radically different ways to how a neoclassical economist would view it. A neoclassical economist would start from the tastes, relative prices and incomes individuals have, and would make an argument about the general level of demand for a good by the aggregation of preferences across individuals. In the neoclassical system it is individual demand that drives demand for products, and signals to producers what to produce of each good and how to distribute resources between goods.

In The General Theory, when discussing shortrun output determination, we see the whole process reversed. In the classical system, and especially in Ricardo's work, as Keynes notes, Says law, which means supply creates its own demand, holds. ${ }^{9}$ For Ricardo, demand is simply a residual, the outcome of a complex set of production decisions which determine the consumption power of the different classes through the distribution of income. The fact that a level of income would exist in conjunction with a proportionate level of consumption is taken to be a tautology. Therefore, it is not considered possible that overall demand is ever deficient. Keynes uses Ricardo's way of seeing things, but adds the following imaginative twist: If we see demand in this 'classical' way and, at the same time, we drop the idea that Say's law has to hold -i.e. supply will always create enough demand to trigger full employment in the economy-, we find, instead, that we can start from the production potential of the economy and build the demand that we need to have to make sure the economy reaches full employment. Thus, given the existing level of machinery, social and financial institutions and relations, we can find out how much of the labour can be gainfully employed before starting to run into shortages of labour, machinery or both.

Here Keynes builds on elements of classical theory, and adds a neoclassical, and particularly Marshallian flavour. He takes what in classical theory is effectively long-term analysis, meant to uncover deeper tendencies of capitalism in historical time, and turns it into a partial equilibrium, short-term heuristic that can give us very rough calculations for broad government intervention in the economy. ${ }^{10}$ This neoclassical flavour extends to an important implicit assumption: this kind of economics is a precondition and analytically a step before the discussion of distribution and reform, which is the domain of deep production structures and class interests in classical analysis. Keynes attempts an analytical separation of the problem of distribution from the problem of unemployment, and generally the use of unemployed resources in an economy, to which he gives precedence. It is almost as if, from a liberal point of view, he is arguing: How can anyone be against putting people in employment and giving them an income if this comes at no-one's expense, but adds to general gain and profit in society?

It may seem paradoxical that Keynes retains the ethical position of neoclassical economics, where it is embedded in the all-powerful sovereignty and equality of individual decisions, to an entirely different system of economic analysis. Classical political economy explicitly accounts for power politics as its analytical structure explains the creation of surplus value and its distribution. Therefore, it is able to incorporate the reason why unemployment is not an unexpected remiss of the economic system, but part of the very system of power politics that production and distribution in society are based on. How can one combine the purportedly a-political moral stance of neoclassical economics, with an economics that partly resembles classical theory?

\section{Human agency, uncertainty and unemployment}

The previous section on production spoke about the multiplier as a type of partial equilibrium tool that Keynes introduces to discuss determination of output and employment in the short run. ${ }^{11}$ The multiplier is the most elaborate tool of the assortment of new

\footnotetext{
According to Keynes, effective demand is an old term, emanating from the work of Thomas Robert Malthus. Keynes claims to have re-introduced this concept into theoretical analysis and embeds it in a new framework.

"From the time of Say and Ricardo the classical economists have taught that supply creates its own demand" (Keynes, 1936, 18)

10 Chick notes that "Keynes's method is something of a compromise, using the partial equilibrium method to analyse a market taken in isolation, then feeding the results back into the mainstream of economic events, which were themselves moving meanwhile" (Chick, 1983, 15).

11 The development of the multiplier has a long and complex history. The most important and definitive rendering is Richard Kahn's (Kahn, 1931, pp. 173-98) who was "inspired" (Kahn, 1984, 91) in this investigation by Can Lloyd George Do It? (Keynes and Henderson, 1929). The exact history of the development of the multiplier is not relevant to the argument here- what is important is to note how Keynes appropriates and embeds these tools in the overall structure of The General Theory.
} 
tools presented in The General Theory, but we can also find other simple heuristic devises for discussing short-run effects. The analysis of liquidity preference (chapter 15) is another such example, in this case a way to conceptualise the reasons why people hold cash in the modern economy. But The General Theo$r y$ is not a complete box of tricks - if viewed as such it would appear wanting. It is more a method to create new tools that fit the situation at hand, and a method to see and analyse individual action embedded in historical time.

The way the book develops its overarching narrative on how to do economics, and its implicit complex view of the individual form a deep unity. The book's content, organisation and style of writing reflect the mode of thinking, the beliefs, and the character of the author. The General Theory is written in an argumentative and conversational style with Keynes speaking freely in a way that projects the intimacy of a working but busy mind. For the reader to be able to decode the text, they must not only try to understand what Keynes is trying to say but why he is saying it and for what purpose. In this endeavour there is no single solution. The narratives that the reader can create are many and variable - and the intention is to train the reader not in perfecting one narrative, one viewpoint about the economy, but to train the reader in the art of creating narratives and trying to abstract in different ways.

This reader experience and its complex cognitive journey are fundamentally different to treatises in economics which build on deductive logic and employ a high degree of abstraction and simplification to arrive at a unified vision of the economy. Ricardo's (1817) book can be seen as an example of this type of social theorising and Keynes in The General Theory uses Ricardo's approach as a counterpoint to how he is trying to theorise. ${ }^{12}$ In Keynes' method, deductive argument alone is not enough proof for establishing an analytical point's insight into the real world. It is almost seen as a method that can deceive. Keynes seems to be worried that in the distance between reality and syllogism, assumptions that the creator of the syllogism themselves may be unaware of can be introduced. This is why even when he is looking at identities he is investigating them from a number of perspectives. An example of this can be found in chapter six, where he is trying to define income, saving and investment, and to find their relation. He arrives at the outcome that saving equals investment by trying different angles and definitions of seeing the problem. It is as if he is compiling more and more evidence in the form of different perspectives of seeing the analytical problem and arriving at similar conclusions. This inductive method of compiling deductive argument and investigating directly the meaning of the language used appears to be the way that convinced him that this identity makes sense in the context in which he aims to use it.

This points not only to the non-linear thought patterns Keynes engages in, but also to the complexity with which he imbues individual action. The individuals that populate The General Theory are psychologically complex persons that are part of the fabric of society as it unfolds in historical time. Their motivations, interests and perspectives of the social world are a combination of insight, logic, imagination, convention and strong social norms. Their actions are based on understanding what they can and cannot do in every situation that arises as it emanates from their perception of their environment. This perception is both how they analyse this particular situation and, at an abstract level, of how they think society in general works. Their actions, but also the psychological imprint of their actions, are not invariant to the social conditions in which they act. Keynes writes in relation to unemployment:

When involuntary unemployment exists, the marginal disutility of labour is necessarily less than the utility of the marginal product. Indeed it may be much less. For a man who has been long unemployed some measure of labour, instead of involving disutility, may have a positive utility (Keynes, 1936, 128).

Thus, for Keynes, the very act of work is seen differently by the individual when there is general unemployment, to times when everyone is employed. The psychic calculus employed by individuals deciding to supply longer hours of work, for a person who is fully employed and decides the benefits of overtime pay against the pain of another hour of labour is not in any abstract way analogous to the problem of a person in long-term unemployment who may find, after much effort, part-time employment in a business. Even the same individual, finding themselves in these dissimilar situations in different parts of their life would engage in new ways of making sense of their environment. The way they understand and analyse these situations changes as the individual accumulates experience and forms new narratives of how the world works, and what is their place in it.

The above brief analysis of human agency and its complex psychological makeup gives us an indication of the difficulty individuals face across a range of decisions and actions they have to take. As a response they find simplifications when thinking about specific problems that allow them to take decisions. Keynes identifies some of these simplifications, when, for example, he discusses the choice between saving and consuming, realising that this can be seen as a two-step process. In chapter 12, he writes:

\footnotetext{
2 His antithesis to the Ricardian method of analysis is also evident in his life of Robert Malthus, who Keynes claims was the first of the Cambridge economists (see Keynes, 1933).
} 
The psychological time-preferences of an individual require two distinct sets of decisions to carry them out completely. The first is concerned with that aspect of time-preference which I have called the propensity to consume, which,..., determines for each individual how much of his income he will consume and how much he will reserve in some form of command over future consumption.

But this decision having been made, there is a further decision which awaits him, namely, in what form he will hold the command over future consumption which he has reserved (stress in original, Keynes, 1936, 166).

This example shows that individuals try to think about the decisions they have to take procedurally, by separating a complex problem into smaller fairly self-contained steps. An added complication to the fact that agents have to find heuristics to break down complex decisions to be able to act, is the uncertainty they face.

There are two types of uncertainty that are pertinent to this discussion- uncertainty about the present and uncertainty about the future. ${ }^{13}$ One fundamental insight of The General Theory is that for the individual, even the present is to some degree unknown. Our perception of reality is a combination of facts, and keys to understand these facts. These are narratives that explain and give meaning to these facts and create the basis for taking action. Where perspectives end and facts begin is itself a line which holds little agreement among different persons. Individuals may designate as facts different parts of their narratives, and indeed may themselves change these demarcation lines as their understanding of a situation evolves, or as their perspectives shift.

Uncertainty about the present stems from two factors, one is from the concept of the individual, who is sovereign enough to construct their own understand- ing of a situation and has the ability to act according to their decisions from a range of choices, and second from the inherent complexity of the modern economy, which defies any single individual from having complete knowledge of what is happening. Traditional societies in which the concept of the individual is less central in determining human action and where production and consumption decisions are substantially less complex would not experience this type of uncertainty. ${ }^{14}$ If these societies are technologically stagnant and socially stable they would not experience future uncertainty as well. ${ }^{15}$

In contradistinction modern social organisation faces both problems at once. Individuals face uncertainty concerning the outcomes of the choice they make, because their decisions depend on simple heuristics, judgements based on narratives and understandings of the situation and the broader social context. Even if nothing changes in the real situations that individuals are facing, agents may change their actions only because their understanding of the situation has changed. This single change may have ripple effects that are, to some degree, unknown and unknowable to the individual. ${ }^{16}$ This is compounded by the problem of a very complex network of production and distribution decisions that operate at any point in time and, of unknown and unknowable products, opportunities and social conditions, that will appear in the future.

The outcomes of all this is a social system that arrives at market valuations for goods and services through a path-dependent historical process partly led by accounting definitions of cost and partly by chance and other economic and social factors that solidify valuations of goods into prices. These prices together with the mechanisms - markets or other institutional environments - that deliver them are seen as conventions. ${ }^{17}$ However, these prices are in precarious

3 In the following discussion I see uncertainty as a problem of knowledge, before it becomes a problem of action. In this I am following an interpretation of Keynes (1937A) who elaborated on his view of uncertainty as different to a problem of merely distinguishing "what is known for certain from what is only probable" (Keynes, 1937A, 213). What Keynes meant is "the prospect of a European war is uncertain, or the price of copper and the rate of interest twenty years hence, or the obsolescence of a new invention, or the position of private wealth-owners in the social system in 1970 . About these matters there is no scientific basis on which to form any calculable probability whatever. We simply do not know" (Keynes, 1937A, 214). One way to see this is what Paul Davidson calls "nonergodic uncertainty" (see Davidson, 1991, 143, and Davidson, 2007, 2011). An extension of this insight is to see the problem facing the individual on the knowledge of their immediate economic, social and institutional surroundings as also part of the same fundamental problem.

14 The individual perspective, as a concept, is a fairly modern invention. Most traditional societies (not all) have interpretations of facts delivered in narratives which have special authority (e.g. religious texts), and mechanisms that discipline any member of the community departing from this interpretation of facts. This meant that human action and choices are, to a large extent, the outcome of a hierarchical or social decision-making process, with little individual human agency. That modernity is defined by this individual perspective combined with a degree of autonomous action brings forth this entirely new form of agency, and the social structures that support and enable it. This means that action is now based more on narratives that are particular to the individual and their view of the environment as they perceive it.

15 I leave outside the discussion on uncertainty that has to do with changes in the physical environment out of human control, or the control of the particular society. Therefore, I do not discuss uncertainty that relates with natural disasters, epidemics, wars or hordes of barbarians passing by and therefore to some degree unknown events that are faced by all societies in human history. Some of these events may have known probability distributions (and indeed equivalent to what Keynes said about the weather as only moderately uncertain (Keynes, 1937A, 214)) other more radically uncertain (an asteroid hitting earth), but share the following important attribute: they are not particular to capitalism, or the new forms of uncertainty the market economy brings forth. Sustained technological progress I take to be different, first, because it is particularly identified with the industrial revolution and therefore with the advent of capitalism, and second, because it challenges consumption and production decisions at the individual level, in new ways that are particular to this system of social organisation and opens up completely new and unimagined spaces of thought and action.

6 "Actually, however, we have as a rule, only the vaguest idea of any but the most direct consequences of our acts" (Keynes, 1937A, 213).

17 As Latsis (2005) notes, a convention is a structure "that is essentially arbitrary, neither an 'optimal solution', nor a solution that conforms to 
stability as outcomes of social convention, as they are not the product of a narrative - religious or otherthat has special social meaning for this community, or the outcome of an invariant way that accounts for the cost of production that individuals can easily check and appeal to. They are taken as given only because they are serviceable to some degree, and perceived to be acceptable by the large majority of individuals that they directly relate to either as producers or as consumers. Accepting these valuations and the authority behind them is a necessary cognitive simplification that the social environment delivers to individuals and they take as a social fact, in normal conditions, when making their decisions. ${ }^{18}$

How individuals make decisions and its relation to socially accepted valuations is one thing. The psychic importance or value individuals ascribe to goods is another. The problem of perception at an individual level has been broached above, but the broader social ramifications of this understanding have not been discussed. The outcome of this realisation is that there is no inherent reason why the value an individual ascribes to a particular good is also the market price. A trivial example is a family heirloom. The market valuation may be determined by fashions regarding the tastes for that good, conventions regarding whether there is an established markets for it, scarcity of similar objects on offer, etc. But the valuation one ascribes to these artefacts partly depend on the associations that object has for them, and may decide to sell this artefact only in abnormal situations like times of serious need. The broader point is less obvious and hints to the fact that for a large volume of goods that individuals deal with, either their valuation mirrors the market valuations because they accept the authority of the social conventions that delivers the observed prices, and they admit them as fair valuations when they decide what to buy, or are in violent disagreement with these prices because they do not accept the social mechanism that delivers this pricing. ${ }^{19}$

This problem of variance between what one believes to be a fair value and the market value is a systemic problem of the market economy, and does influence a whole range of goods and services. Keynes, however, was not worried about small injustices that are a necessary evil of existence, but more with deeper problems in market valuations that could upset the very precarious economic and social balance of the system. It is for this that he focuses the whole of The
General Theory on the problem of unemployment. He sees employment, and the price it commands, the wage rate, as the preeminent social problem an individual faces in the capitalist economy.

For the individual, the problem of employment can be seen to be both the most complex market decision and the most psychologically charged one. It is so charged because it is at the nexus of the narrative the individual constructs about themselves and their relation with society in general, through its pre-eminent mechanism of valuation, the marketplace for labour. If the individual completely rejects the valuation that the market ascribes to their labour, either because they cannot find any proper job, or the wage they receive does not allow them to live in a way they and their social peers find acceptable, then their trust in the market as a mechanism of valuation in general falls into question. In capitalist bourgeois society, market prices, although they determine distribution, do not have the moral weight and justification that traditional societies ascribe to their distribution of work and goods that come through religious and secular texts and are supported by established social hierarchies. What remains as a social defence mechanism is simply the weight of the majority and their trust in the system, i.e. the narratives the individual constructs about the overall acceptability and fairness of the market system. In conditions of economic crises and depression, the number of people that lose trust in the system, mostly because they lose their jobs and therefore their ability to command resources as consumers and their place in society as full productive members, grows. This creates a dynamic of extreme social and economic instability. Keynes wrote:

Men will not always die quietly. For starvation, which brings to some lethargy and a helpless despair, drives other temperaments to the nervous instability of hysteria and to a mad despair. And these in their distress may overturn the remnants of organization, and submerge civilization itself in their attempts to satisfy desperately the overwhelming needs of the individual. This is the danger against which all our resources and courage and idealism must now co-operate. (Keynes, 1919, 144)

\section{The general theory's view on material civilization}

any universal social law" (Latsis, 2005, 726). Therefore, the very construction of market frameworks and their price and quantity exchanges are part of an historical social process in an environment of uncertainty (see Latsis, 2006, Latsis et. al., 2014).

18 That this view is radically different to a supply-demand framework for determining prices, quantities and market interaction was observed by an early reader of Keynes, Roy Harrod. When reading The General Theory in galley proofs he wrote to Keynes in August 1935 "Its effectiveness [of the GT] is diminished if you try to eradicate very deep-rooted habits of thought unnecessarily. One of these is the supply and demand analysis... It is doing great violence to their fundamental groundwork of thought, if you tell them that two independent demand and supply functions won't jointly determine price and quantity" (Keynes, 1973, 533-4). Keynes replied "[but] my whole point is that the functions in question are not independent" (Keynes, 1973, 538).

19 Recent work on conventions has focused on how they are both arbitrary and normative. Al-Amoudi and Latsis (2014) note how "a convention is not the unique response to a given social situation" (Al-Amoudi and Latsis, 2014, 359) and at the same time "conventions are also widely seen as normative binding in some weak sense" (Al-Amoudi and Latsis, 2014, 359). And yet while conventions have some plasticity to adopt as conditions change, there are situations where the agent can refuse to accept to conform, exactly because they are understood to be arbitrary. 
The outstanding faults of the economic society in which we live are its failure to provide for full employment and its arbitrary and inequitable distribution of wealth and incomes (Keynes, 1936, 372).

Keynes could not, for all its faults, allow capitalism to meet its end. This was both because he was as a liberal, believing that the systems' virtues outweigh its injustices, and because he could not see an alternative better system of social organisation that could take its place. The outcome is that The General Theory both tries to save capitalism and pays tribute to its attractive features. Keynes does this by creating a utopian vision of an imaginary social system that combines the dynamism of the free market with an enlarged government sector that acts to buttress against the excesses of the market system.

The basis of the utopian vision, as in all treatises of political economy from the enlightenment until Keynes' time, ${ }^{20}$ is a theory of the progress of material civilization. This analysis completes Keynes' systematic view of the capitalist system, and adds a third alternative to both the 'economics of scarcity' and the 'economics of production and distribution'. In his theory consumption, production and human agency are given new roles and meanings on how they create and sustain the material basis of civilization. This new vision of the social order that forms The General Theory's utopia comes centre stage in chapter 24, but glimpses can be found across chapters and it is the theme that holds the book together.

Utopian visions are necessarily long-term perspectives on the economic and social order. Keynes directly borrows the method of Adam Smith's Wealth of Nations and sets this long-term analysis firmly in historical instead of abstract time..$^{21}$ This allows him to discuss long-term tendencies of the market system and, to speak about the evolution of institutions and their position in the economic order. This theory of material progress comes through in different examples and vignettes in various parts of the book, and it is more an accumulation of insights, methods and realistic hopes about the possibilities for the current system rather than a comprehensive blueprint of how to reform society. It can be reconstructed in a number of ways, and one way to do so is by starting from the following quote:

Ancient Egypt was doubly fortunate, and doubtless owed to this its fabled wealth, in that it possessed two activities, namely, pyramid-building as well as the search for the precious metals, the fruits of which, since they could not serve the needs of man by being consumed, did not stale with abundance. The Middle Ages built cathedrals and sang dirges. Two pyramids, two masses for the dead, are twice as good as one; but not so two railways from London to York. Thus we are so sensible, have schooled ourselves to so close a semblance of prudent financiers, taking careful thought before we add to the 'financial' burdens of posterity by building them houses to live in, that we have no such easy escape from the sufferings of unemployment (Keynes, 1936, 131).

One of the central elements of The General Theory is not only to re-establish the insight that at any point in time demand may fall short of its appropriate level, that is, the level that clears the labour market, but also that it re-instates demand as an important element in long-term analysis. This it does by re-evaluating the importance of the individual in the economic system, and the way individuals imagine and can transform the future. Let us, for a moment, follow Keynes, think somewhat wildly, and take seriously the problem of building pyramids. A long time ago a Pharaoh, akin to God, ruled over the Old Kingdom of Egypt. He had a chancellor called Imhotep, who, from what we can tell from archaeological evidence, was a genius and an architect and created for his pharaoh the first step pyramid of Egypt. This started a trend of building pyramids that lasted over 500 years. Many pharaohs that followed built bigger, more technologically advanced - more exact in proportions and measurements - and refined versions of the original idea. The reason was that it was the custom of that land that the king would, after his death, be interred in a tomb, and he needed a tomb that would be equivalent to his station in life, and his status vis-à-vis his ancestors. This created a societal need for continuously larger and better pyramids, and the process of improvement was a continual one until we reach the reign of Cheops about 100 years later, the builder of the great pyramid of Gyza, the largest pyramid of the Old Kingdom. After that the pharaohs who followed could not really compete with this achievement and Khafra and Mykerinos built smaller pyramids next to the great one. The trend of pyramid building continued for centuries, until the very social organisation of the Old Kingdom fell into chaos, as central administration seem to have collapsed and many local rulers gained semi-independence and vied for the crown. This was the end of the Old Kingdom and the beginning of what archaeologists call the first intermediate period that led to the middle kingdom - a very different period of Egyptian art and culture.

Building pyramids is no simple business. Apart from technological knowhow, you need also to command substantial labour power, which should be available for long periods of time to do extremely arduous work. You need to find new solutions for organising the workforce as you scale up produc-

20 Keynes writes of himself and his intellectual milieu "of another eighteenth-century heresy we were the unrepentant heirs and last upholders. We were among the last of the Utopians..." (Keynes, 1938, 447).

21 For example, in his chapter on the theory of prices (chapter 21) he writes "So far, we have been primarily concerned with the way in which changes in the quantity of money affect prices in the short period. But in the long run is there not some simpler relationship? This is a question for historical generalisation rather than for pure theory." (Keynes, 1936, 306) 
tion, change the chain of production as you improve measurements, have more exacting standards and use better building material, and find ways to provide for labour during this period of work. In ancient Egypt, with limited external trade, the food surplus produced from the agriculture sector should be great enough to cover the labour cost devoted to the construction of the pyramid until it is complete. This society would need to find new and sophisticated ways of collecting, storing and distributing food from the agricultural sector to the pyramid building sector. In modern parlance, they would need to develop new financial instruments that can support the new complex production process that is needed to deliver the good that the central bureaucracy is bent on building. From this perspective, finance is another way to say a social agreement on provisioning. It is simply claims from one part of society to another to deliver purchasing power today on the expectation of future returns - in this world or the next. ${ }^{22}$

The crucial point is that the creation of financial tools is not separate from the production process. On the contrary, it is the reason sophisticated production can take place. Pharaohs had to have not only warehouses to keep the food that they needed for the workforce, but logistics to keep account of the stock and some distribution network to give out proper meals to the workers. Then they needed some mechanism to restock depleting provisions in warehouses, and foresee the provision needs over - at least - the next few months, and capacity to do financial planning over long periods of time or the pyramid would not be finished. This financial side developed pari passu with technological achievements, the management of the workforce knowhow, and the increased ability of the agricultural sector to produce enough of a food surplus to sustain the workforce working on the pyramid. All this activity was driven by the demand for a good by a centralised bureaucracy run by a living God and his - socially embedded - tastes.

This elaborate example gives a theory of the forces that shape material civilization that is different from both the neoclassical and classical perspectives. The neoclassical viewpoint, which has as its organising principle scarcity and choice, cannot encompass this dynamic view of material change driven in a sustained fashion from demand. In neoclassical theory, individual preferences, together with competition from producers, determine prices in the various markets of goods, and increases in demand in some sectors bid away resources from others, as production follows the sovereign tastes of consumers. But the overall logic of the system is that it is generally constrained by scarcity, with demand across sectors following the increased productivity from new technology that becomes available.

The classical view is difficult to discuss succinctly as e.g. David Ricardo and Karl Marx built different systems that cannot be easily summarised for the purposes of this paper. Without attributing this view to any individual author, let us assume, for contrast, that by and large the classical view, at least in part, is the following: production and distribution arise from the technological basis and from the social and institutional relations of the community. Over time, as technology advances, it enables and, to some degree requires, the development of new and more sophisticated structures of social and institutional relations that come into existence. This material basis together with the institutional structures which exist in direct relation to and symbiotically with, give rise to a surplus over and above what this society needs to reproduce its productive potential. This surplus is divided through the interplay of class and other interests, as institutional and other social relations dictate. As this surplus grows, a consequence of the increasing ability of technologically sophisticated societies to re-produce and expand their capital base, so does its distribution became an issue in the social arena that can create instability and economic crises. ${ }^{23}$

The above brief outline gives both an historical materialist and a teleological narrative to the classical position. Although it does not do justice to any one classical writer, it is a useful narrative for showing the differences with this reading of Keynes' General Theory. In Keynes' position, the interplay of capital formation, production and demand is less unidirectional. Material conditions give the potential for the creation of a complex production system but not the certainty. For example, although agriculture on the river Nile could produce enough surplus to build the great pyramid of Giza, it did so only once over 500 years that the Old Kingdom existed. The question is what happened to this surplus over these other periods? One can argue that war, natural disasters, etc. made the surplus fluctuate over time. Also mistakes in technology — not all pyramids survived construction - political and dynastic instability meant that some investment went to waste. All of these observations are true to some extent, but they miss the point, which is that the surplus does not exist independently of the demand for pyramids. The demand for pyramids necessitates the creation of new social institutions that could support the increasingly complex production process. Increasing demand gave

\footnotetext{
In Keynes' own terms "In what follows I use the term "finance" to mean the credit required in the interval between planning and execution" (Keynes, 1937, 663: footnote 2).

23 This presentation of the classical position is not intended to be exhaustive or representative of all authors of previous eras, even major ones, (Adam Smith) who have a complex and varied following. It intends to represent a very simplified form of some strands of the Ricardian School in order to show the difference with this reading of The General Theory. Keynes himself in chapter 23 of The General Theory builds a narrative of alternative ways of seeing the economy. For example, he repeatedly mentions Robert Malthus as a forerunner of his economics both in The General Theory and in his life of Malthus (Keynes, 1972, 71-103) and in chapter 23 is sympathetic to many mercantilist writers.
} 
rise to a system in which the creation of agricultural surplus and its distribution are two sides of the same coin. With the collapse of demand for the creation of pyramids either because of political instability and/or because this competition with building bigger pyramids reached its resource limits, this surplus was not diverted to other uses, it ceased, over time, to exist. As the institutions that came into existence for the production of pyramids atrophied, with it the very sophisticated organisation of the land that provided the produce devolved. In the end the technology of how to build great pyramids was lost, and with it knowledge of how to finance such projects in a society that had, from the modern perspective, such limited means. ${ }^{24}$

This creates a vision of material progress in which material conditions do not uni-directionally determine the future. Material conditions both create the space for human agency, and also human agency creates the material conditions that are necessary for technological advancement. At the other end, crises that lead to revolutions are possible but not inevitable, and the potential of secular stagnation and other kinds of deterioration of a technologically advanced civilization over time due to chronically deficient demand introduced as a prospect. In this view, human agency through social and financial institutions comes centre stage in creating and sustaining material prosperity.

The problem that Keynes identifies is that there is no automatic tendency through which this happens, and the market system in no way guarantees that this high employment position will be reached in the short run or the long run. In fact, there is reason to expect that the market system continually underperforms in this regard. Fundamental uncertainty and the profit motive drive the capitalist to be somewhat conservative about the future, and to plan according to the logic and habits of the past. ${ }^{25}$ The outcome of this tendency is for the system to veer towards chronic underemployment. Keynes identified this problem in the chronic tendency of industrial society to have a higher rate of interest than is necessary. In a provocative fashion, he claims that interest cannot, any more, be seen as a reward for saving, but simply the outcome of power relations in the money market. The ability of the capitalist to exploit the scarcity value of capital and demand interest payment is a social artefact. "There are no intrinsic reasons for the scarcity of capital" (Keynes, 1998 [1936], 376) and if the capitalist refuses to save and invest under these new conditions, the state could cover this gap through social provisioning.

At the same time, low rates of interest and cheap credit by themselves may not lead either to growth and a more equitable distribution or reduced unemployment. The core problem emanates from this new type of uncertainty that is the defining feature of this social system. Uncertainty of this kind allows and even leads individuals to speculative activity. In a system that does not display uncertainty, either because it does not possess enough complexity in production or/and has no strong tendency to action derived from individual motives, as most activities follow fairly established societal rituals, speculation makes a limited, if any, appearance. In these cases what financing there is, is of a habitual nature. In traditional societies that display an evolving and increasingly sophisticated production pattern, some degree of financial speculation may start to appear. For example, it can be imagined that one of the scribes/ builders who kept stock of the great warehouses of a pharaoh building their pyramid, may have decided to borrow a few sacks of corn to celebrate his daughter's wedding to a high ranking official, expecting to pay it back from profits he earns in smaller building projects he does on the side. It is reasonable for him to expect more business due to his increasing influence in court. Of course the scribe would never steal from his God and Pharaoh, but would very well borrow from him without telling him. This side loan by itself would not really endanger the production of the pyramid, as finance could be stretched in this way, and by further extending credit in this speculative way marginally increase aggregate demand in the economy at no one's cost. ${ }^{26}$

However, it is with the modern conception of the individual that speculation comes into its own. Individuals who see themselves as possessing substantial freedom of action to pursue their own ends; Individuals who believe they have the ability and right to form an independent understanding of situations and have the means and legal rights to act on their beliefs. Furthermore, if a broad class of people, in this social framework, are given access to markets and institutions in which speculation for profit is the norm, the

\footnotetext{
It is useful here to juxtapose this position with a quote from the celebrated restatement of the Classical position by Sraffa (1960). He writes "One effect of the emergence of the surplus must be noticed. Previously, all commodities ranked equally, each of them being found both among the products and among the means of production; as a result each, directly and indirectly, entered into the production of all the others, and each played a part in the determination of the prices. But now there is room for a new class of 'luxury' products which are not used whether as instruments of production or as articles of subsistence, in the production of others. These products have no part in the determination of the system. Their role is purely passive" (Sraffa, 1960, 6-7). Sraffa notes that this is a natural way to think of Ricardo's system (Sraffa, 1960, 111). This is a different understanding of the capitalist system to The General Theory, which implicitly sees production of goods in an economy in a more organic way. Thus, collapse of demand in one sector, would mean collapse of aggregate demand that would affect all sectors over time, and eventually the very nature of social organisation, even if there was no explicit mutual production relationship between these sectors to start off with. This difference in the two visions is explored in (Lee and Jo, 2011). But this does not mean that dialogue is impossible (see Martins, 2011, 2013, 2014).

25 Although progress comes from the opposite impulse -the entrepreneur's natural tendency to almost unfounded (in logic) optimism that is “our decision to do something positive, the full consequences of which will be drawn out over many days to come, can only be taken as a result of animal spirits- of a spontaneous urge to action rather than inaction... "(Keynes, 1936, 161)

26 If, of course, all officials started on the same racket things would be rather different.
} 
system develops new forms of dynamic instability. Keynes writes:

It is usually agreed that casinos should, in the public interest, be inaccessible and expensive. And perhaps the same is true of stock exchanges. That the sins of the London Stock Exchange are less than those of Wall Street may be due, not so much to differences in national character, as to the fact that to the average Englishman Throgmorton Street is, compared with Wall Street to the average American, inaccessible and very expensive....The introduction of a substantial government transfer tax on all transactions might prove the most serviceable reform available, with a view to mitigating the predominance of speculation over enterprise in the United States (Keynes, 1936, 159-60).

The above quote gives us a flavour of the very complex role the state plays in the new utopian vision of The General Theory. It is not only to make sure that full employment is achieved, but to become a whole other field of activity that reviews and modifies market behaviour- and yet does not stifle the liberty of individual agency. Keynes is neither pining for an idealised traditional society, nor for a full socialisation of production, and with it a centralisation of narratives of human need and required action. He writes that if we find a system that deals with these excesses "the traditional advantages of individualism will still hold good" (Keynes, 1936, 380). And there are many benefits to individualism, that range from gains in efficiency -if you enable individuals to take some ownership of the processes they are involved in - to happiness, as individuals who display agency find meaning in what they do.

Which returns us to the question that was posed in Section 2. How do we combine a view of society that has individual freedom and liberalism as one of its core values, and at the same time deal with a system that naturally leads to substantial instability, uncertainty and in the end crisis or stagnation? Are we left with no alternative than finding the right balance between the special interests of the different sectors of society which are in natural conflict and impose this enforced balance on them?

Keynes' utopian social vision was part of the enlightenment tradition. He believed in creating spaces that aligned social interests through reason and argument, instead of the need of power politics with the inevitable narrative of winners and losers. Uncertainty has an unexpected positive consequence; no one can be absolutely secure in their knowledge of either everything in their environment or their future. In fact, even in cases when substantial parts of the problem are known, a reordering of complex facts in new narratives may yield entirely new understandings. Thus, the possibility of people not knowing what really is in their interest at every point in time should not be discounted. If this is a pervasive feature of the system what remains is to convince people to change their perspective, their narrative of the situation as they understand it. The argument behind Keynes' theory of material civilisation is that it is in everyone's interest to make sure that demand remains high, because this sustains the very nature of economic surplus that adds to the spoils of those in power - even if the interests of the groups on how these spoils are to be distributed is in tension, unemployment is to no-one's benefit.

Furthermore, if this agreement is achieved, it forms the basis for more common ground to be found in a variety of other fields. ${ }^{27}$ Aligning objectives is a process of social interaction and evolution in the same way that bartering for conflicting aims is. Both processes have at their core understanding the issues, conflict, adaptation, change and at least a modicum of social agreement in the process of give-and-take and its limits. What differs is the emphasis they place on these concepts and as a consequence the direction their imagination takes in finding solutions to their problems. ${ }^{28}$ The event spaces that these two processes arrive at are fundamentally different - because the conflicting parties use their energy in a different fashion and are willing to come up with another set of solutions to their real and perceived needs.

Within a society that has achieved, or is willing to experiment with, this kind of social engineering, the economist can play an enlarged role and different to the one envisioned in neoclassical and classical economics. Between the view of the economist as a specialist dealing in technocratic matters for the benefit of efficiency or to redistribute resources between individuals given a political mandate, and the economist who focuses on class interests and their clash in the socio-political arena, there is the economist who works in developing broadly consensual change, being fully aware of the moral implications of their suggestions and enacting an acrobatic balance between realities, needs, practical limitations and imagination.

The technical part of the job is to come up with heuristics that can achieve specifically set social objectives. This is in the tradition of the Marshallian $\mathrm{Ce}$ teris paribus analysis. Taking everything else which appears to be given as given, then one can analyse the relation of key variables to each other. Although Keynes uses the same process as Marshall, the conceptual foundation of the Ceteris Paribus clause is different. Marshall used it as a tool to do partial anal-

\footnotetext{
The fact that the eclipse of unemployment would lead to a transformation of the social relations between classes, and as such will be resisted, was observed very early on by Keynesian economists. Kalecki in 1943 noted "It is true that profits would be higher under a regime of full employment that they are on average under laisser-faire; [but business leaders'] class instincts tell them that lasting full employment is unsound from their point of view.."(Kalecki, 1943, 326).

28 This re-imagining was not meant to be easy, as Kelecki noted in 1943. Sheila Dow wrote exactly 30 years ago "The lesson to be learned from the experience with the General Theory over the last 50 years is that 'changing the way the world thinks about economic problems' is an extremely difficult task..." (Dow, 1988, 109) And so it remains.
} 
ysis of an integrated economic system that was, in its broad contours, known; i.e. a market economy organised around individual preferences and production costs. The assumption was that immediate effects could be separated from the second rate effects influencing other more remote markets. For Keynes the clause is to separate parts of the system which the economist can reasonably guess to be known and impose a narrative on them, from the complex reality which is, at the moment, and will remain in its totality, essentially unknown and unknowable. Thus the The General Theory is not so much a work of theory of how the economy works, but a work on method for how the economist should work. Keynes writes:

The onset of our analysis is, not to provide a machine, or method of blind manipulation, which will furnish an infallible answer, but to provide ourselves with an organised and orderly method of thinking out particular problems; and, after we have reached a provisional conclusion by isolating the complicating factors one by one, we then have to go back on ourselves and allow, as well as we can, for the probable interactions of the factors amongst themselves. This is the nature of economic thinking. (Keynes, 1936, 297)

The non-technical part of the job of the economist is to imagine the creation of institutions and solutions that would further foster common ground dynamics in the social sphere. Uncertainty is both the challenge that threatens social organisation and the opportunity for humane solutions. In this process The General Theory can act as an apocryphal mental anchor for the reader. ${ }^{29}$ The Keynesian economist is like an architect inheriting a medieval cathedral centuries in the making, with a book of blueprints that don't fit together, grand ideas most of which never came to pass and examples that don't exactly fit the present. And yet they would be lost without the book. It is how they see the cathedral. It is on whose pages their ideas take shape and from which they learn how to reason. It is how they keep the cathedral from becoming a ruin. Keynes, towards the end of his life, eloquently opined on the economists and their social mandate:

I give you the toast of the Royal Economic Society, of economics and the economists who are the trustees not of civilization, but the possibility of civilization. (Harrod, 1951, 193-4)

\section{The General Theory and the Post-Keynesians}

This paper explains how The General Theory develops a new way of economic theorising that is distinct to the classical and neoclassical perspectives. The importance of uncertainty as the core message of the General Theory follows an interpretative line that emanates from the work of George Shackle, Hyman Minsky, Geoffrey Harcourt, Victoria Chick, Sheila Dow and others, and gave rise to this strand of Post-Keynesian analysis. This reconstruction is not intended to be an exact expression of their views, but it shares with them key elements and especially how uncertainty is a pervasive feature of the modern economy, and an organising principle around which a distinct view of the social and economic system can be constructed. That this is the defining ontological feature of the economic system is an assumption of this particular strand of Post-Keynesian analysis, and other strands would read The General Theory from a completely different perspective and, construct narratives of its message using other core principles. ${ }^{30}$ This interpretation gives a unified picture of The General Theory by adopting the position that its perceived disjunction is part of its message. This is not an uncontroversial statement. A reader who wants to see how the different chapters of The General Theory can give rise to independent broad narratives can start on this path by reading Harcourt and Riach (1997).

Harcourt's contributions can be used to understand how three important aspects of this strand of Post-Keynesian analysis come together. In Harcourt (1987) we find that Keynesian thinking has three central pillars: the whole is more than the sum of the parts, agents act in a context of inescapable uncertainty, and in order to understand the complex nature of reality we need a plurality of languages and approaches. ${ }^{31}$ This methodological plurality is further discussed in Harcourt (2001) where he speaks of his experience in using different frameworks of economic analysis to gain insight in different aspects of the world and its workings. This perspective sees both classical and neoclassical theory as useful viewpoints in understanding aspects of the modern economy. Both viewpoints have many uses, not always in contention, as useful mental constructs that shed light in parts of the current social and economic reality and the ways we understand and act upon it.

The deep commitment to a pluralist approach in understanding the economy is an outcome of the central role uncertainty plays in this world view. Because of uncertainty, the accumulation of knowledge depends on cross examination of theoretical positions that emanate from different perspectives and therefore are grounded in differently constituted views

\footnotetext{
As Gotti (1994) argues "The General Theory is one of the few non-literary texts in which the author, willingly and knowingly, gives the reader not merely the role of decoding the text and assenting to the views propounded, but an altogether more demanding and important role as the author's collaborator in the working out of the final form and the exact meaning of the new economic theory" (Gotti, 1994, 186).

30 A starting point on the different strands of Post-Keynesian economics can be found in Harcourt (1987A) or Harcourt (2006). For alternative narratives on Cambridge Post-Keynesian analysis and its relation to classical and neoclassical theory see Pasinetti (2007) and Martins (2014).

31 This is very close to Lawson's key notions of internal relations, open systems and a pluralist ontological framework (see Martins, 2013A, 66). Lawson in (Lawson, 1997, 2003) explores the ontological and methodological groundwork for this approach.
} 
of the world. This is the way theorists broaden their horizon and find new insights on the nature of social reality. Dow $(1990,1996,2010)$ grounds the basis of this insight in ontological differences across schools of thought and in different conceptions of the mind. Part of the training of the economist is to "think how they think" 32 , and therefore become reflective of the whole process of theorising and its ontological and methodological underpinnings.

In conclusion, we can summarise this paper's interpretation of The General Theory in the following way. First, part of the classical analysis on production interdependencies and consumption norms can be seen as useful devices in analysing the economy at every point in time and affect short run changes, depending on what the objectives of the economist are. These heuristics of short period analysis and action are not a complete set of tools, but evolve through time as the economy changes. Second, the deeper key analytical insights of The General Theory are a complex understanding of the individual that builds narratives about their environment and their place in the social order, and the inherent uncertainty these narratives engender. Uncertainty defines not only the actions of the individuals, but also what the individuals understand of the world around them. In an effort to make sense of their complex environment individuals use shortcuts, and rely on established institutions, often, in the modern economy, markets and the price system. These market valuations are conventions and are perceived as such by market participants. The convention of the labour market stands separate exactly because through its pricing, the wage rate, it influences the relation of the individual with society. That is why it has such a prominent place in the world of The General Theory. Third, these insights both of heuristics to be used by economists to make sense of the world and of the deeper complex structure of modern capitalism constitute a particular viewpoint of what creates and sustains material civilization. At one end this viewpoint argues that aggregate demand has a role that is fundamental to material prosperity and its full conceptualisation is quite different to what classical and neoclassical analysis ascribe to it. At the other that the nature of modern capitalism and the uncertainty it brings forth both for the individual and for society at large necessitates new modes of thinking by the economist whose narratives and action can help sustain the delicate social balance from dangers, both old and new.

\section{References}

Al-Amoudi, I., J. Latsis, 2014, “The arbitrariness and normativity of social conventions", The British Journal of Sociology, 65(2), 358-378. DOI: 10.1111/1468-4446.12042

Chick, V., 1983, Macroeconomics After Keynes. A Reconsideration of the General Theory, Cambridge: MIT Press.

Cord, R., 2007, Keynes, London: Haus

Clarke, P., 2009, Keynes. The Twentieth Century's Most Influential Economist. London: Bloomsbury.

Davidson, P., 1991, "Is Probability Theory Relevant for Uncertainty? A Post Keynesian Perspective", The Journal of Economic Perspectives, 5(1), 129-143. DOI: 10.1257/jep.5.1.129

Davidson, P., 2007, John Maynard Keynes, New York: Palgrave Macmillan.

Davidson, P., 2011, Post Keynesian Macroeconomic Theory, 2nd ed., Cheltenham: Edgar.

Dow, S. C., 1988, "What happened to Keynesian Economics?" in Hamouda and Smithin (eds.), Keynes and Public Policy after fifty years. Volume I, Economics and Policy. Aldershot: Edward Elgar, 101-110.

Dow, S. C., 1990, “Beyond Dualism”, Cambridge Journal of Economics, 14(2): 143-157. DOI: 10.1093/oxfordjournals. cje.a035123

Dow, S. C., 1996, The Methodology of Macroeconomic Thought, Cheltenham: Edward Elgar.

Dow, S. C. 2010. "Was there a (methodological) Keynesian revolution?”, in Dimand, R. W., Mundell, R. A. and Vercelli, A. (eds), Keynes's General Theory after Seventy Years, London and New York: Palgrave Macmillan, 268-86.

Gotti, M., 1994, "'The General Theory" as an Open-Ended Work" in Marzola A. and F. Silva, (ed.) John Maynard Keynes. Language and Method, Aldershot: Edward Elgar, 155-192.

Harcourt, G.C., 1987, 'Theoretical Methods and Unfinished Business', in D. A. Reese (ed.), The Legacy of Keynes, Nobel Conference XXII, San Francisco: Harper and Row, 1-22.

Harcourt, G.C., 1987A, "Post-Keynesian Economics" in John Eatwell, Murray Milgate and Peter Newman, The New Palgrave. A Dictionary of Economics, London: Macmillan, Vol. 3, 924-7.

Harcourt, G. C. 2001. "How I do economics" in 50 Years a Keynesian and Other Essays, London: Palgrave, $323-33$.

Harcourt, G.C., 2006, The Structure of Post-Keynesian Economics: The Core Contributions of the Pioneers, Cambridge: Cambridge University Press.

Harcourt, G.C. and P.A. Riach (eds), 1997, A 'Second Edition' of The General Theory, 2 volumes, Routledge: London and New York.

Harrod, R., 1951, The Life of John Maynard Keynes, London and New York: Macmillan.

Hayes, M.G., 2019, John Maynard Keynes, Cambridge: Polity Press

\footnotetext{
32 Interview with Sheila Dow 13 July 2016 available at http://www.economicsppf.com/sheila-dow.html
} 
Kahn, R.F., 1931, “The Relation of Home Investment to Unemployment”, Economic Journal, 41 (162) pp.173-98. DOI: $10.2307 / 2223697$

Kahn, R.F., 1984, The Making of Keynes' General Theory, Cambridge: Cambridge University Press

Kalecki, 1943, "Political Aspects of Full Employment", Political Quarterly, 14(4), pp. 322-31. DOI: 10.1111/j.1467923X.1943.tb01016.x

Keynes, 1933, "Open Letter to the President", originally published in The New York Times reprinted in Vol. XXI , The Collected Writings of John Maynard Keynes, Activities 1931-1939: World Crises and Policies in Britain and America, 1987, Cambridge: Cambridge University Press, pp. 289-304.

Keynes, J.M., 1919, The Economic Consequences of the Peace, republished as Vol. II of The Collected Writings of John Maynard Keynes, 1971, London: Macmillan for the Royal Economic Society

Keynes, J.M., 1933, “Thomas Robert Malthus", republished in Vol. Xof The Collected Writings of John Maynard Keynes, 1972, London: Macmillan for the Royal Economic Society, 71-108.

Keynes, J.M., 1936, The General Theory of Employment, Interest and Money, reprinted as Vol. VII of The Collected Writings of John Maynard Keynes, 1973, London: Macmillan for the Royal Economic Society.

Keynes, J.M., 1937, "The "ex ante" theory of the rate of Interest" Economic Journal, 47: 663-9. DOI: 10.2307/2225323

Keynes, J.M., 1937A, “The General Theory of Employment” The Quarterly Journal of Economics, 51:2, 209-223. DOI: $10.2307 / 1882087$

Keynes, J.M., 1938, "My Early Beliefs" in Vol. X of The Collected Writings of John Maynard Keynes, 1972, London: Macmillan for the Royal Economic Society, 433-450.

Keynes, J.M., 1972, The Collected Writings of John Maynard Keynes, Vol. X: Essays in Biography, London: Macmillan for the Royal Economic Society

Keynes, J.M., 1973, The Collected Writings of John Maynard Keynes, Vol. XIII: The General Theory and After: Part I, Preparation, London: Macmillan for the Royal Economic Society.

Latsis, J.S. 2005, “Is there redemption for conventions?” Cambridge Journal of Economics, 29: 709-727. DOI: 10.1093/ cje/bei023

Latsis, J., 2006, "Convention and Intersubjectivity: New Developments in French Economics", Journal for the Theory of Social Behaviour, 36:3, 255-277. DOI: 10.1111/j.1468-5914.2006.00307.x

Latsis, J., G. de Larquier and F. Besis, 2010, “Are conventions solutions to uncertainty? Contrasting visions of social coordination" Journal of Post Keynesian Economics, 32:4, 535-558. DOI: 10.2753/PKE0160-3477320402

Lawson, T., 1997, Economics and Reality, London: Routledge.

Lawson, T., 2003, Reorienting Economics, London: Routledge.

Lee F.S., and T.H. Jo, 2011, “Social Surplus Approach and Heterodox Economics” Journal of Economic Issues, 14 (4), 857-875. DOI: 10.2753/JEI0021-3624450406

Martins, N., 2011, "The Revival of Classical Political Economy and the Cambridge Tradition: From Scarcity Theory to Surplus Theory”, Review of Political Economy, 23 (1), 111-131. DOI: 10.1080/09538259.2010.510319

Martins, N., 2013, "Classical Surplus Theory and Heterodox Economics", American Journal of Economics and Sociology, 72:5, 1205-1231. DOI: 10.1111/ajes.12045

Martins, N., 2013A, "The Nature of the Cambridge Heterodoxy", Revue de philosophie économique, 14 (1), 49-71. DOI: 10.3917/rpec.141.0049.

Martins, N., 2014, The Cambridge Revival of Political Economy, London and New York: Routledge.

Pasinetti, L.L., 2007, Keynes and the Cambridge Keynesians: A 'Revolution in Economics' to be Accomplished, Cambridge: Cambridge University Press.

Repapis, C. (2014) 'J.M. Keynes, F.A. Hayek and the Common Reader'. Economic Thought, 3.2, pp. 1-20.

Ricardo, D., [1817] 1911, The Principles of Political Economy and Taxation, London; New York: J.M. Dent and Sons.

Robbins, L., [1932] 1935, An Essay on the Nature and Significance of Economic Science. London: MacMillan and Co.

Sheehan, B., 2009, Understanding Keynes' General Theory, Basingstoke: Palgrave Macmillan.

Skidelsky, R., 2006, "Hayek versus Keynes: The road to reconciliation", in E. Feser (ed.) The Cambridge Companion to Hayek, Cambridge: Cambridge University Press, 82-110.

Skidelsky, R., 2010, Keynes: A Very Short Introduction. Oxford, Oxford University Press

Sraffa, P., 1960, Production of Commodities by Means of Commodities: Prelude to a Critique of Economic Theory. Cambridge: Cambridge University Press. 